CEW :DIF $\mathrm{V}-3$
DEPARTMENT OF COMMERCE

BUREAU OF STAND ARES

WASHINGTON

June 9: 1932 .
Letter

Circular IC 331

(Superseding Circular No.95)

This letter circular is for the benefit of the numerous correspondents who ask how to make various kinds of inks. In it are given the formulas for the standard inks in several Federal specifications, and selected formulas of inks for which there are no specifications.

Nethods of testing are omitted, because the average user of ink is perfectly satisfied if it has a good color and works well. Those who wish to test inks canfbuy copies of the specifications. see last page.

Manufacturers and others frequently misunderstand the puroose of the formulas for the standard inks in the specifications. It is not required that inks supplied to the Government shall be made strictly according to the formulas, but only that the inks so supplied shall be equal to the standard inks in every essential quality. This applies especially to the first two of the inks, because the materials used in their formulas must be of the purity established by the United States Pharmacopoeia. By suitable chemical control of his manufacturing processes, anyone who can make ink from cheaper raw materials is at liberty to do so and may sell his product to the Government, if it is as good as the standard ink. Of necessity the materials used in the standard inks must be of the same purity, so that both seller and butyer will know exactly what is wanted.

\title{
Weights and Measures.
}

In some of the formulas the ingredients are in "parts by weight". By choosine an appropriate unit it is evident that the formulas can be used for making the inks in any quantities desired. In most of the formulas metric units are used, and lest the unaccustomed reader should be discouraged at the outset, a few conversion factors are given. 

I gram equaIs 15.43 grains, or 0.0353 oz. avoir.

I oz. avoir. equals 28.35 grams

I Ib. avoir. equals 453.6 grams

1 liter equals $1.0567 \mathrm{U} . \mathrm{S}_{\text {. Iiquid quarts }}$

I milliliter equals 0.0338 liquid oz. (The milliliter

is commoney but wrongly celled cubic centimeter)

1 U.S. Iiquid gallon equals 3.785 liters

I U.S. Iiquid oz. equals 29.57 milliliters

1 gram per liter equals 0.1335 oz. avoir., or 58.4 grains, per U.S. Iiquid gallon.

For all practical purjoses, a milliliter of water weighs 1 gram. By definition, this is exactly true at $4^{\circ} \mathrm{C}\left(39.2^{\circ} \mathrm{F}\right)$. other liquids weigh more or less, in proportion to thoir donsities. Required weights of liquids can be converted into volumes if their densities are known. Thus, if the density of the liquid is 1.30 , that of mater being 1.00 , a given weight, say 100 grams, of the liquid will have a volume of $100 / 1.30$, or 76.9 milliliters. This holds for only ono temperature, strictly speaking, but it is accurate enough for the present purpose, at other temperatures.

Ink: Copying and Record. Tederal specificetion TT-I-52I.

All the ingredients in the standard ink must be of the quality prescribed in the current edition of the United Statos Phormacopoeia.

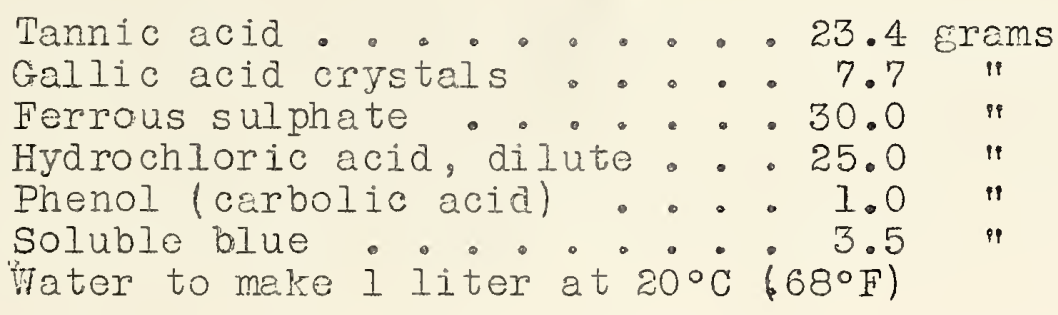

Here as in all other formulas, "water" means aistilled water, if it can be had. Rain water is second choice.

Dilute hydrochloric acid, U.S.P., is of 10 por cent strength. concentrated hydrochloric acid as commonly sold is a water solution containing about 36 per cent by weight of hydrochloric acid gas, so as to make the 10 per cent acid, 100 parts by reight of concentrated acid must be diluted with 260 parts by weight of vater. 


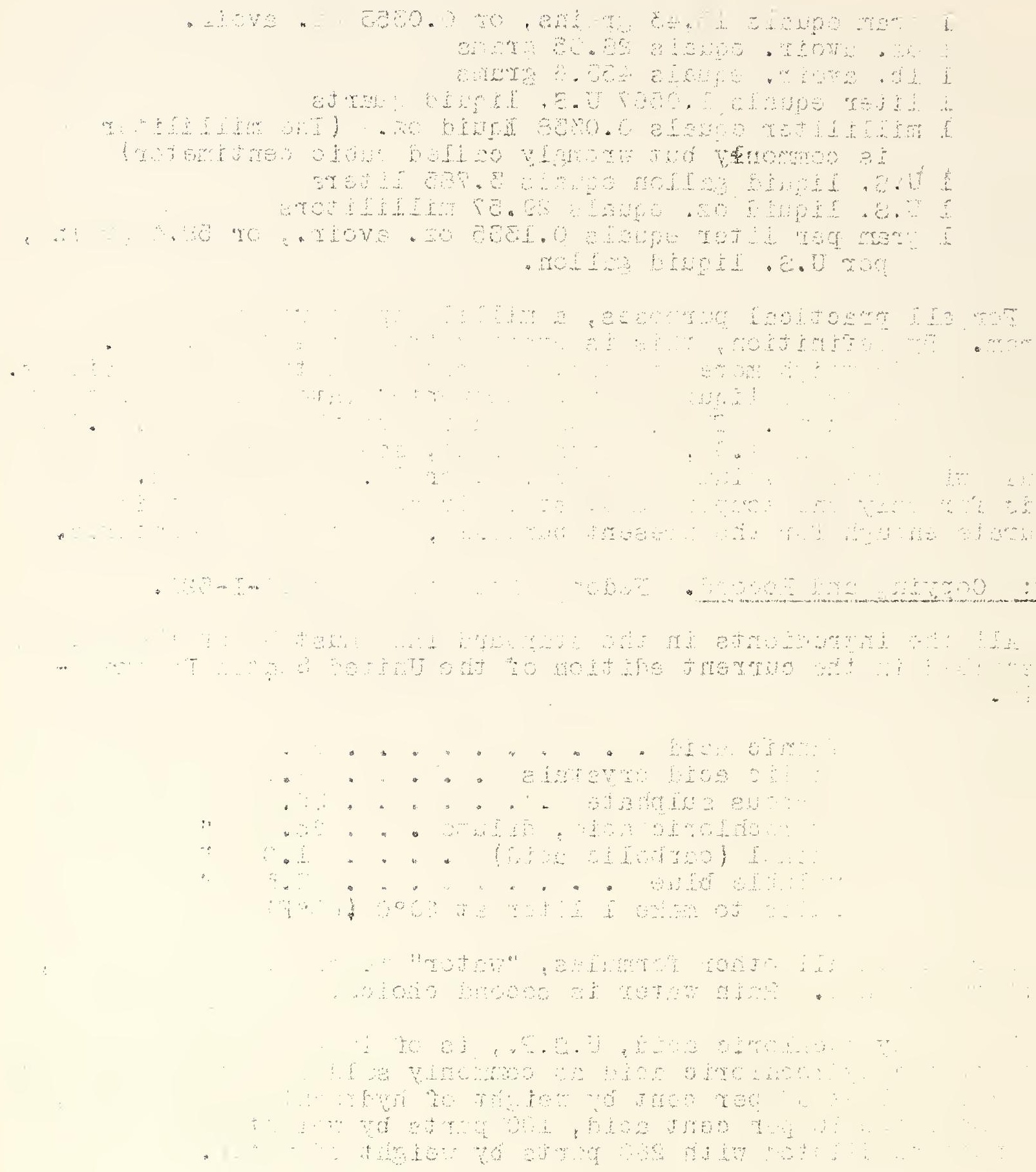


Soluble blue is one of the comparativeiy few dyes that are not precipitated by the other ingredients of tho ink. When buying a supply of it, be careful to say that it is to be used for maing ink. See the list of dyes on a later page of this letter.

To make the ink, dissolve the tannic and gallic acids in about 400 milliliters of weter at a temperature of about $50^{\circ} \mathrm{C}$ ( $122^{\circ} \mathrm{F}$ ). Dissolve the ferrous sulphate in cbout 200 milliliters of warm woter to which hes been sdded the required mount of hydrochloric acid. In another 200 mililiters of wrirm moter dissolvo the dye. Mix the three solutions and add the phenol. Rinse ench of the vessels in wich the solutions were mede with a small quantity of weter, and use the rinsinôs to make the volume of ink up to l liter at room temperature. Be sure the ink is well mixed before it is bottled. If sealed hermeticrlly in a glass bulb, the ink rill keep for yens with practicrlly no form tion of sediment. So when bottling the ink, have good ti ght corks and fill the bottles almost to the corks.

This ink is primarily for records, and is not like most copying inks. However it rill make one good press copy when the miting is frosh, and this vill generrlly suffice.

Ink: Writing. Federal Specificetion TT-I-563.

Except for the phenol and dye, this ink is half as concentroted as the record and copying ink. It is similar to some of the commercial writing pluids and fountiin pen inks. The stondard is made in the same way as the preceding ink, and from materials of the some quality. If made with slichtly nore hydrochloric acid than the formula cells for it will kecp longer thout depositing sediment, but it will be more corrosive to steel pens.

The standard formula is:

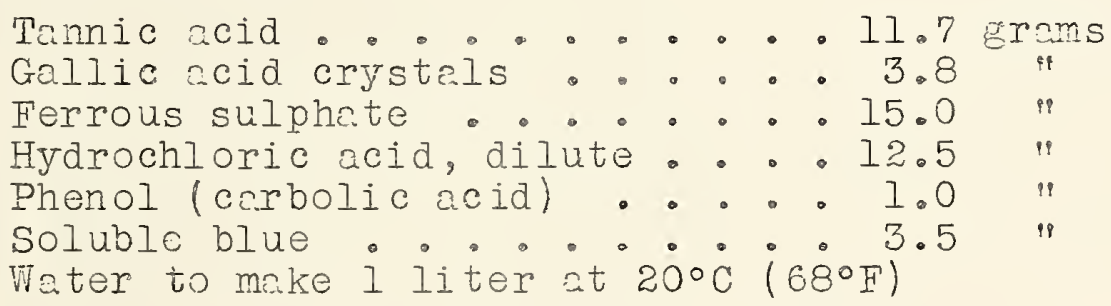



Concentrated Ink, Powder and Tablets. Feder. I specification TT-P-56:

Concentrated ink thnt meets all the requirements of the specification cen be made by cutting down the amount of moter to a minimum, so as to make ? pasty mss or a thick fluid with the solids only prrtly dissolved. Insterd of hydrochloric acid, which is volr.tile, an equivalent quentity of sulphuric ncid is used; that is, 1.77 grams of the usunI concentreted ncid of 95 per cent strength (66 deg. B\&aume).

Ink powders and trblets were included when the specificntion was written, though all thrt had boen examined up to thet time were either a dye, for instance nigrosine, or wholly uns?tisfactory mixtures purporting to make good iron gello-tannete ink whon

dissolved in water. A fer months before this letter circuls.r ras witten, one manufacturer succeeded in making an ink powder that meets all the requirements. This Burenu is not able to say how this powder is made.

Ink: Red. Feảeral specifitiotion TT-I-54\%。

The standard ink is made by dissolving 5.5 grms of crocein scarlet $3 B$ in 1 liter of wr.ter.

other Colored Inks.

There are no Federal specifications for inks of other colors than red. Any weter-soluble dye dissolved in water can be used as ink, though not all dyes are equally suitable for the purpose. It is useless to give a general formula for the rmount of dye to dissolve in a given volume of water, becruse of the greet differences in tinting strength. With some dyes more, and 泣 th others less then the 5.5 grams pcr liter specified for crocein scrilet, would be requirod. If the quantity of dye available is small, moke a concentrated solution and dilute it by degrees until it wites with a satisfactory depth of color. It is not safe to depend upon its appearnce in the bottle. Many dyes hrve an antiseptic action, but solutions of others vill become roldy, and it is necessery to provent this by menns oi phenol or some othor preservetive. One grom per liter is onough. In case the ink shows? tendency to blur or "fonther" on good mititing papor, dissolve. 1 or 2 per cent of gum arabic in it.

As olready said, most ink powders and tablets consist of watersoluble nigrosine. A much more attractive color is n?phthol bluebleck, though it is not ns permanent as nigrosine. 


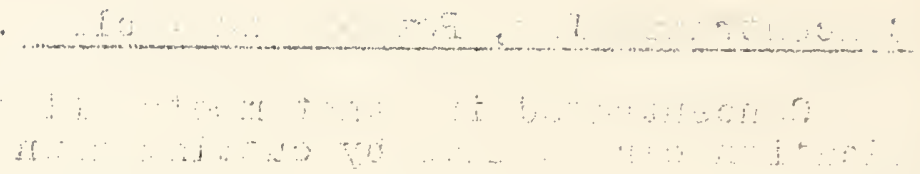

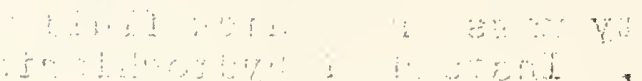

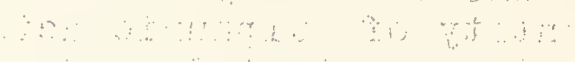

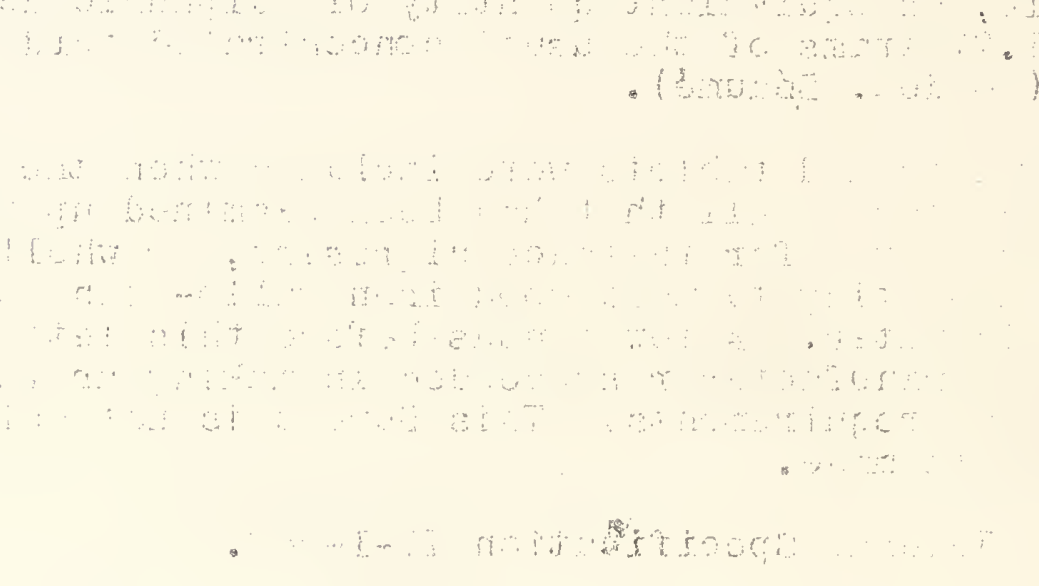


ACid-Proof Inks.

The few semples of acid-proof inks received for test during the course of many yoars were either solutions of prussion blue alone, or they conteined in addition $a$ dye to moke their color darker. They vere labeled "bIue-bIrck", though th t term should be reserved for the iron Enllo-tanne.te inks thet rrite bluo, and turn black on prper.

The usurl form of prussian blue is not solublc in wr.ter, and it is tochnicrlly difficult to make the varicty cr.lled soluble prussian blue. For tunately the pigment con bo gotten into solution by mixing it vith one-fifth or less of its weight of crystnllized oxalic acid. As some of tho bluo may not dissolve, it is a good iden to make the solution with loss mator thrn the formula calls for, and then to dilute it as much as scems desirnble. From 40 to 50 grams of prussinn blue rill probrbly be required with 1 liter of vater. Some of the fev vublished formulas cril for mounts of oxnlic acid up to one-hnlf the weight of the prussinn blue, but tre hove found one-fifth to be ample.

Prussian blue ink resists attack by some acids, but alkaline solutions decompose it ana leave a rusty stain of iron oxide. Ink erndicntors of the ncid-juvelle water type will remove it, though not easily.

Hectograph Ink.

Years before some of the modern duplicating devices had been invented, the hectograph was used for printing small cditions of circular letters, etc., and it is still in rether vide use. The original is mitten with a spocial ink th t contains a large proportion of a dye that has good tinting strength. The letter is then pressed face-downward upon a geletin-glycerin or a clayglycerin pad, which absorbs a considerable smount of the ink. From this pad it is possible to print a number of increasingly paler copies upon other sheets of paper. The neme, hectograph, "hundred miting", exaggerates sonewhat, unless copies so pale cs to bc barely legible are counted. In exporimenting with quites number of dyes, it was found that the following mould give at lorst 30 copies with unbroken lines, and numerous other copies that vere easily legible, though there vere breaks in the strokes of the pen. Methyl violet grve tho most copies, the best red dye wns rhodamine $B$, nnd emerald green and Victori? blue were the best of their colors.

The ink used in making these tests mas propared according to the formula: 



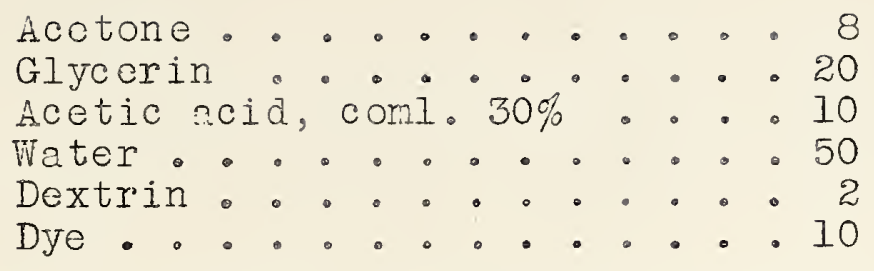

All perts are by weight. If the unit chosen is 1 gran, the formula rill make about 90 milliliters of ink.

Stamp-Pad Ink. Foderai Specification Tr-I-556.

A solution of dye in vater could bo uscd on a stamp ped, but it would soon dry out. A mixture of equel volumes of glycorin and rater remains noist under all stmospheric humiditios, though the water content of the misture fluctuates. In each 100 milliliters of the mixture of glycerin and water dissolve 5 grams of dye. The following sere used for meking the strnards of different colors in the specification: water-soluble nigrosine (black), soluble blue, light groen, magente (red), and acid violet.

Recording Inks.

There is no Federal specificntion for rocording ink. For outdoor recording instrumonts the dissolving about lo grams of dye in 1 liter of a mixture of equal volumes of glycerin and water. is this mixture will froeze in some parts of the country, it is sometimes nocessary to rdd a certain proportion of alcohol to the ink.

For recording instruments in the leborstory, the ink needs to contain only enough glycerin to prevent its drying at the tip of the pen. A mixture of 1 volume of glycerin and 3 volumes of writer has been found satisfactory.

Almost any vater-solublo dye might be used nere it not that some of them rather unaccountably make blurred lines on the usus card and papor charts. Dyes that heve been found to work vell are cracein scarlet, fast crimson, brilliant yellon, emerald green, soluble blue, methylene blue, mothyl violet, Bismarck brom, and mater-soluble nigrosine。 

Indelible Mrking Ink. Foderal Speciric tion TT-I-542.

No formula for a standerd mrking ink is given in this specificntion. Of the numerous formulas in books, those conteining a silver salt, and others designed to produee miline black on and in the fibcrs, are most common. A typical formule of ench kind is here given.

Dissolve 5 grams of silver nitrate in its own veight of weter, and add cmmis. we.ter (not household cmonid) until the precipitate that first forms just dissolves. Sop r.taly dissolve 5 grms of gum r.rbic in 10 milliliters of werm weter, nd 3 groms of cnhydrous sodium carbonete (or 3.5 grans of the monohydrote) in 15 mililiters of rom vater. Mix the three solutions and ram until the mixture strrts to darken. This ink should be used ii th ? gold or a quill pen if possible, but if not, ith? clenn steel pen. The miting should be exposed to direct sunlight or prossed with a hot iron to develop the color. Tha ink must be kept in the dork.

Anilino blnck inks rro made in one or in two solutions, the crgument for the latter being that tho chemicnl renction thet produces the color must take place largely in the fibers where the mark is wnted. Therc is no chnnce for the color to be formed in the bottle before the ink is opplicd to the froric, and to moke a sediment thet crn not penetrete into the fiburs. Howevor, excellent one-solution inks crn be bought.

For a two-solution ink the following hes been recommended:

Solution fo-

Copper (cupric) chloride . . 85

Sodium chlorate . . . . . 106

smmonium chloride ..... 53

Water ......... 600

Solution B.-

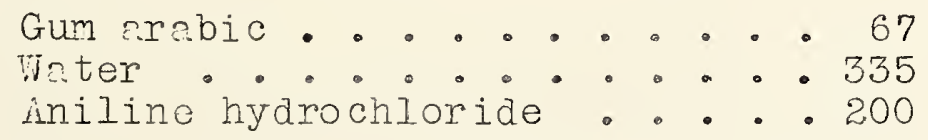

Keep in seprrate bottles. Immediatoly before use mix $I$ volume of $i$ and 4 voluries of $B$. 



\section{Draning Inks.}

There is at present no Federal specific-tion for draning ink. The comrercial block arning inks re suspensions of crrbon in a W.: ter solution th t contains substances which keep the particles of carbon from settling to the bottom, and which usually mike the marks on psper or tracing cloth weterproof when they once become dry. Shellac dissolved in . dilute solution of bornx, or of bornx and mmonis, is believed to be the usunl reterproofing sgent, snd it clso acts $\mathrm{s}$ s "protective colloid" to keep the crrbon in susponsion. Success in meking cerbon inks sems to depend party upon long-continued grinding in $\mathrm{s}$ ball-mill.

Comprotively fer colored drowing inks se modo with pigments, but are clear solutions of dyes. Most of then aro crlled werproof, but all that we he.ve examined "bled" alittle when lines drawn with then vere kopt under slight pressure in contact ith a piece of vet pepor. This is a very severe test. is it is not procticrble to make waturproof colored inks in the home, the process noed not be described.

Sympathetic or Invisible Inks.

It rould be absure to mite a specifice tion for ink thrt is intended for secret ressages or rocords. The grentest variety of substances crn be used for ink of this kind, snd some of then hr.ve been known and used for meny centuries. The following moteriols, found in every hone, ar a potential sympsthetic inks: alum, soda (baking and veshing), borax, flour boiled with plenty of water, corn sirup thinned with water, sonp, diluted mucilnge, milk, lomon juice, and silive. Sone or these rre very poor, indeed, but could be used if nothing better vere at hond. sluri is by for the best, boing about $\mathrm{s}$ good ss a drop of sulphuric r.cid, for instnnce from a store ee battery, mixed ii th ton or a dozon drops of rater. Dilute sulphuric acid has beon used for many jears. The writing in all these cases is devoloped by pressing : ith ? hot iron, or holding it above = gas flame so that the paper begins to turn broin.

Mny invisible inks are developed by chenicol trontment, preferably by fuming, but by the appli crtion of solutions when necessriry. Thus, the vepors of ammonium sulphide vill form brom or black sulphides of tho metrls, when the inks contain criy of the following: iron (ferric) sulph te, mercuric chloride (corrosive sublimete), copper sulphate, cobrlt chloride, nickel chloride and lead ceetr.te. Some of these silts re colored, but tho solutions crn be so dilute s, to bo invisiblo on prper. Cobelt 

chloride becomes deep blue in dry ir or when hen.ted noder tely, and vith strong herting the viriting becomes permenently black. Forric sulphote turns black ith tonnic coid, nnd blue tith potassium ferrocyanide. The vopor from solid iodine turns sterch ink blue. It will even bring out frintly riting done with distilled reter on some kinds of prper, beceuse the sizing is disturbed by the mater, and this allows the paper to absorb more of the iodine vajor whore it was retted.

\section{Specinl Inks.}

Some of the books listed on a 1-ter page give formulns for meking inks for rriting on metals and other spocial surfaces. Most of the formuliss hrve not been tried by us, nd tho inks ire not used to sny grent extent, so it seems unnecessary to dovote any sprece to thern.

\section{Pigment Inks.}

Once a formule has been rorked out for an ink thet is composed of a mixture of liquids, or of solids dissolved in liquids, it is easy to duplicote the ink at nny tine; sssuming of course thet the ingredients are of tho some purity ns roquirod by the formule. The situation is aifferent if the ink consists of one or more pigments mixed with a fluid. In that cese a formulr. simply gives an idea of how to nake the ink, because the physicnl properties of the nixture depend largely upon how the materials cre put together. The successful producer of pigment inks must heve skill based upon experience. Besides blcck drnning ink and some uith colored pigments, there cre various kinds of printing inks, cenceling, duplicsting or mimeograph, nnd other kinds in this closs.

\section{Dyes for Ink M...king.}

There are many nore names of dyes than there are kinds, because manufacturers like to have special names for their products. This readily leads to confusion in speaking or viriting about dyes. To give an example: Bismarck brom, Manchester bromn, phenylene brown, vesuvine, aniline bromn, leather brom, cinnamon brown, canelle, English brom, golden brom, brown Y, and brown extra are nanes for the sme dye, and this is not the vorst case that could have been selected. To do amay ith this sort of confusion, tio important compilations of dye nemes have been made. These are Schultz's Frabstofftabellen (dyestuff tables), and the colour Index. In ench of these books are brought together all the comercial nemes by which each dye type is known. Bismarck brom and 

the other dyes just namod heve the srme chemicnl composition and structure, and are therefore of the same type. In the books, onch dye type is given a sorial number, which thorefore sorvos as = sort of spocificetion for the type. Insteod of soyine Bismrek brown, the buyor could get it by asking for Colour Index 150.332 or schultz No. 284.

Thoso who like varioty con make witine and othor inks of numorous colors and shades by using the dyes in the list. They cro grouped rccording to color, in the smo order cos/tho spectrum, followed by bromn and black.

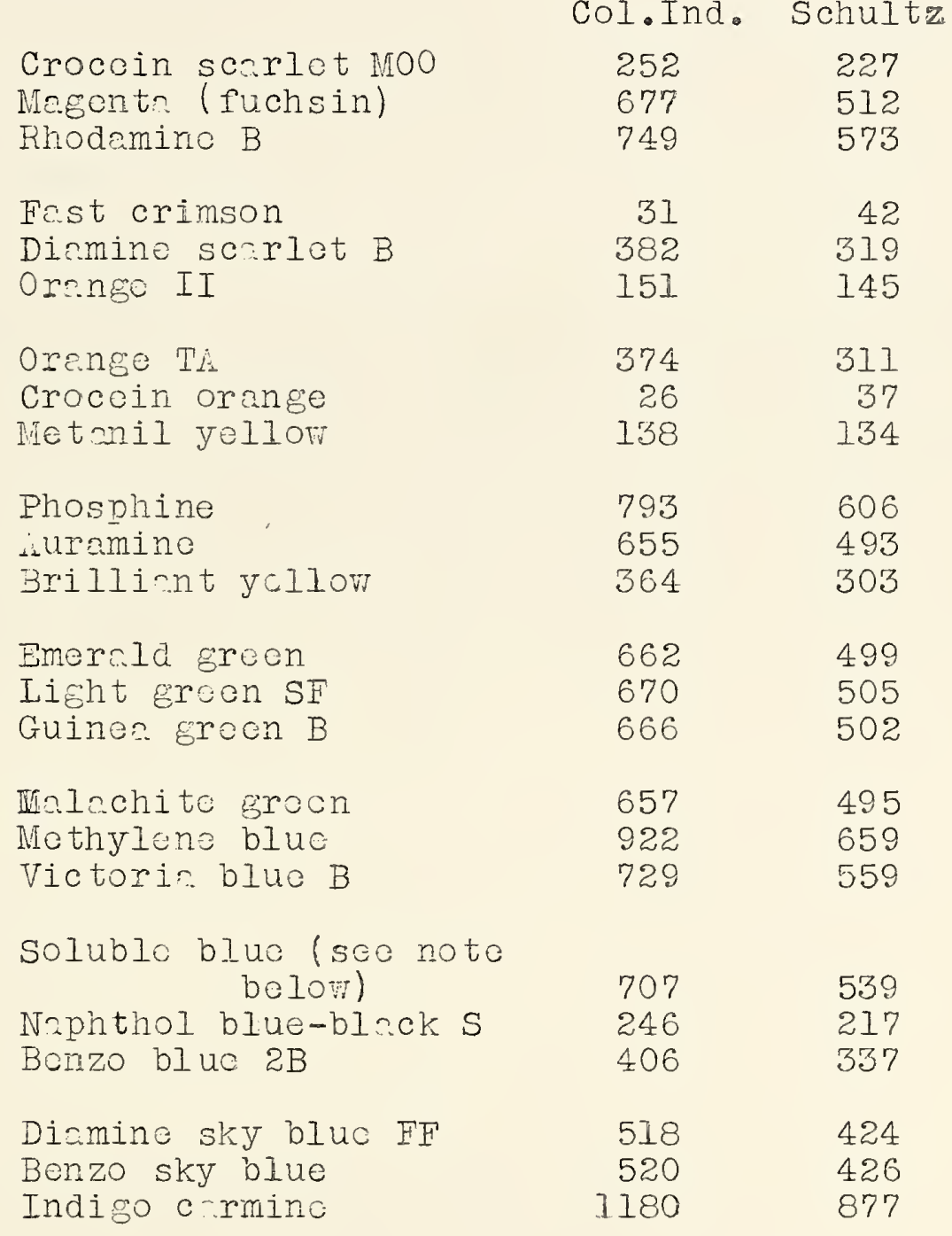





$\begin{array}{lll}\text { Methyl violet B } & 680 & 515 \\ \text { Crystal violet } & 681 & 516 \\ \text { Acid violet } & 698 & 530 \\ \text { Alkali violet } & 700 & 532 \\ \text { Bcnzaminc brom 3GO } & 596 & 476 \\ \text { Bismarck brom R } & 332 & 284 \\ & & \\ \text { Durol bleck B } & 307 & 265 \\ \text { Nigrosine, water-soluble } & 865 & 700\end{array}$

Note: i special effort may have to bo mode to obtnin soluble blue thet can be usod in iron gallo-tennete ink wi thout forming an insoluble procipitate with the iron or the tannic and gallic acids. Unless the blue is made "for ink", it may not be usable. One cen alvays return to indigo cermine (sodium selt of sulphonited indigol, which was usca before the days of synthetic dyes. other dyes worth trying because they do not form precipitates, aro naphthol bluo-black $S$, benzo direct blue $2 B$, benzo sky blue, and diamine sky bluc FF. They are not ns bright in color es soluble blue, and they should not be adopted as substitutes for it without rigorous testing over c: period of several months, in comparison with soluble blue that is known to be satisfectory.

In senor: I it is adviscble to buy dyes directly from the menuiacturer, and to specify the concentrated form in eech case. Miny dyes are mixed with inert diluents before beine put on the mrrket. This is a recognized trade practice, and is not to be regorded as adulteration.

\section{Bibliography.}

There is probabiy no public librery that does not havo severel of the books in the list belor. Some of the books give formulas and little else, while others are concerned chiefly with the technical and scientific side of inks. Of the books listed, Nos. 1, 3, 5, 9 and 10 heve eppecred in more than one edition.

1. Brannt-mahl, Techno-Chemicel Receipt Book. H. C. Baird Company, INew York, 1919.

2. Carvalho, Forty Centuries of Ink. Banks Lav Publishing Company, New York, 1904. 

3. Henley, Twentieth Centur'y Book of Recipes, Formulas and Processes. Norman $W$. Henley Publishine Company, New York, 1928.

4. Lohner, Manufacture of Inks. Scott, Greonsood \& Company, Lundon, 1902.

5. Mitchell \& Hepworth, Inks, Tiseir Composition and Nanufacture. Chas. Griffin \& Company, London, 1924.

6. Rupert, Examination of Hriting Inks, in Industrial \& Ingineering Chemistry, Vol. 15, p.489; 1923.

7. Osborn, Questioned Documents. Larryers: Co-operstive Publishing Company, Rochester, H.Y. 1910.

8. Oyster, Spatula Ink Formulary. Spatula Publishing Corpany, Boston, 1912.

9. Scientific tinusican Cyclopodia of Formulas. Munn \& Company, Inc., Mort York, 1921.

10. Spon, Torkshop Receipts. E. \& F. Spon, L undon, 1917.

11. Unin errood \& Sullivan, Chemistry and Tachnology of Printing Inks. D. Var Nostrand Company, New York, 1915.

12. Miborg, Printing Ink. Hurper \& Bros., Now York, 1926.

Circular No. 95 of this Bureau is on Inlis, Tupemiter Ribbons and Carbon Paper. It is no: out of print, but can be consulted in many libraries. It summarizes the several Federal specifications so that these need not be bought. However, if anybody desires to have them, they can be bought for 5 cents apiece from the Superintendent of Documents, Washington, D. C. Ste., s. mill not be accepted in payment. Thie specifications are no longer issued as Circulars of the Bureau of Standards, and are now designated as follons:

TT-I-52I, I:1k; Copying and Rocord

TT-I-542, Ink; Murking, Indelible (iur) Fabrics

TT-I-549, Ink; Red

TT-I-556, Iisk; Stamp-Pad

$\mathrm{TT}-\mathrm{I}-563$, Ink; Writing

The journal, Cnomical ADstracts, gives abstracts of articles on chemistry and related subjects that are published all over the world. It also cites petents issued in this and other countries. In the two decennial indexes, 1907 to 1916, and 1917 to 1926 , and in the annual indexes since the last date, there are numerous entries relating to inks. 

$\checkmark$

$+2$

$+2$

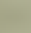


